HENRY MCBRIDE

SERIES IN

MODERNISM AND

MODERNIT Y 
This page intentionally left blank 


\section{Eugene Jolas}

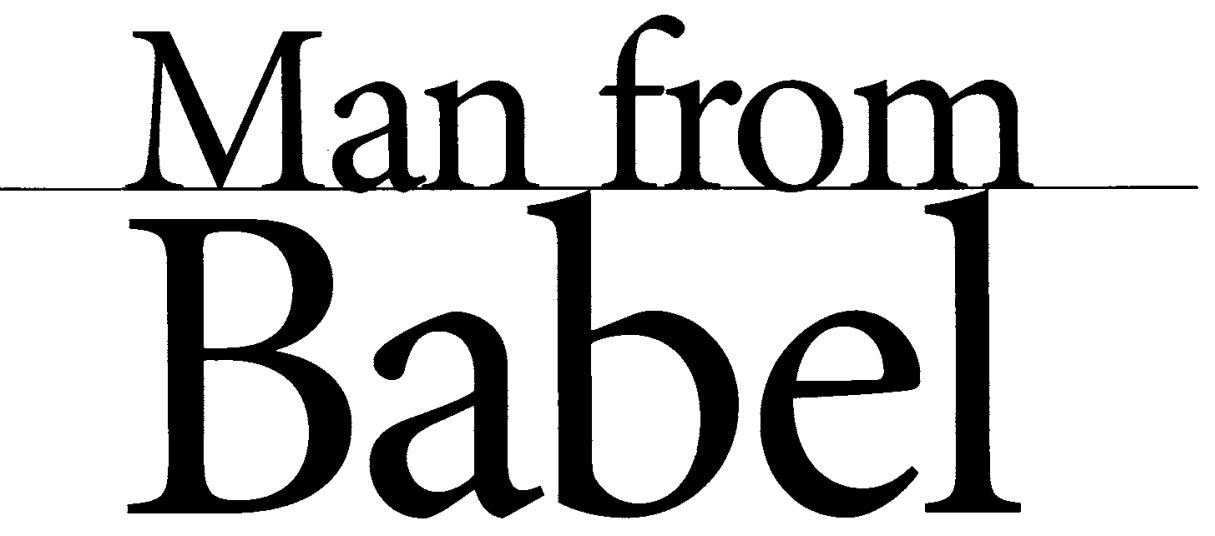

EDITED, ANNOTATED

AND INTRODUCED BY

ANDREAS KRAMER AND

RAINER RUMOLD

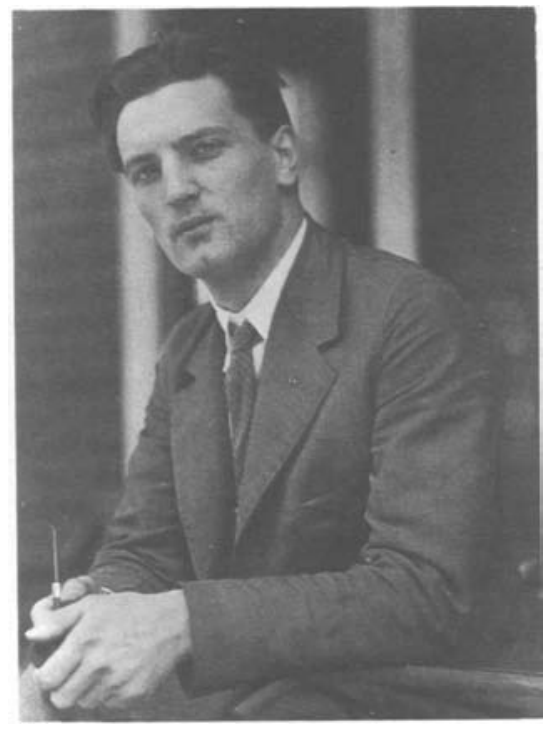

领

Yale University Press

New Haven \& London 
This book has been published with assistance from the fund for the Henry McBride Series in Modernism and Modernity established by Maximilian Miltzlaff.

Copyright $\odot 1998$ by Yale University.

All rights reserved.

This book may not be reproduced, in whole or in part, including illustrations, in any form (beyond that copying permitted by Sections 107 and 108 of the U.S. Copyright Law and except by reviewers for the public press), without written permission from the publishers.

Set in Minion and Gill type

by Tseng Information Systems, Inc., Durham, North Carolina.

Printed in the United States of America by Vail-Ballou Press, Binghamton, New York. Library of Congress Cataloging-in-Publication Data

Jolas, Eugene, 1894-1952.

Man from Babel / Eugene Jolas ; edited, annotated, and introduced by Andreas Kramer and Rainer Rumold.

p. $\mathrm{cm} .-$ (Henry McBride series in modernism and modernity)

Includes index.

IBSN 0-300-07536-7

1. Jolas, Eugene, 1894-1952-Biography.

2. Poets, American - 2oth century-Biography.

3. Modernism (Literature) - United States.

4. Journalists-United States-Biography.

5. Translators - United States - Biography.

6. Editors-United States-Biography.

I. Kramer, Andreas. II. Rumold, Rainer.

III. Title. IV. Series.

PS3519.033Z468 1998

$811^{\prime} .52-\mathrm{dc} 21$

[B]

98-6674

CIP

A catalogue record for this book is available from the British Library.

The paper in this book meets the guidelines for permanence and durability of the Committee on Production Guidelines for Book Longevity of the Council on Library Resources. 
HENRY MCBRIDE

\section{SERIES IN}

MODERNISM AND

MODERNIT Y

The artistic movement known as modernism, which includes the historical avant-garde, produced the most radical and comprehensive change in Western culture since Romanticism. Its effects reverberated through all the arts, permanently altering their formal repertories and their relations with society at large, and its products still surround us in our workplaces and homes. Although modernism produced a pervasive cultural upheaval, it can never be assessed as an artistic movement alone: its contours took shape against the background of social, political, and intellectual change, and it was always bound up with larger questions of modernity and modernization and with the intellectual challenge of sifting their meanings.

Henry McBride (1867-1962), who wrote weekly reviews of contemporary art for the New York Sun (1913-1950) and monthly essays for the Dial (1920-1929), became perhaps the leading American critic to write perceptively and winningly on modern art. He discussed difficult artistic issues in a relaxed, engaging, yet informed style, one that is still a model of clarity, grace, and critical responsiveness. The Henry McBride Series in Modernism and Modernity, which focuses on modernism and the arts in their many contexts, is respectfully dedicated to his memory.

EDITORIAL COMMITTEE

Lawrence Rainey, University of York, General Editor

Ronald Bush, Oxford University

Arthur Danto, Columbia University

Charles Harrison, Open University

Jean-Michel Rabaté, University of Pennsylvania

Jeffrey Schnapp, Stanford University

Richard Taruskin, University of California, Berkeley

Robert Wohl, University of California, Los Angeles 
This page intentionally left blank 